\title{
Physical and compositional characteristics of cheese and yogurt made from partially demineralized milk protein concentrate
}

\section{Características físicas y composicionales del queso y yogurt elaborados a partir de un concentrado de proteínas de leche parcialmente desmineralizado}

\author{
Edinson Bejarano-Toro; José Uriel Sepúlveda-Valencia²; Eduardo Rodríguez-Sandoval ${ }^{3}$
}

\begin{abstract}
'Zootecnista, M.Sc., Ph.D.(c) Universidad Nacional de Colombia, Sede Medellín, Ciencias Agrarias. Medellín - Antioquia, Colombia; e-mail: eebejara@unal.edu.co; (D) https://orcid.org/0000-0001-8508-8387 Administración de Empresas, M.Sc. Universidad Nacional de Colombia, Sede Medellín, Departamento de Ingeniería Agrícola y Alimentos. Medellín - Antioquia,
Colombia; e-mail: jusepul@unal.edu.co; (D) https://orcid.org/0000-0001-5660-4514

${ }^{3}$ Ing. Químico. Ph.D. Universidad Nacional de Colombia, Sede Medellín, Departamento de Ingeniería Agrícola y Alimentos. Medellín - Antioquia, Colombia; e-mail: edrodriguezs@unal.edu.co; (D) https://orcid.org/0000-0001-9146-2419
\end{abstract}

*autor de correspondencia: gojaimet@unal.edu.co

How to cite: Bejarano-Toro, E.; Sepúlveda-Valencia, J.U.; Rodríguez-Sandoval, E. 2021. Physical and compositional characteristics of cheese and yogurt made from partially demineralized milk protein concentrate. Rev. U.D.C.A Act. \& Div. Cient. 24(1):e1949. http:// doi.org/10.31910/rudca.v24.n1.2021.1949

Open access article published by Revista U.D.C.A Actualidad \& Divulgación Científica, under Creative Commons License CC BY-NC 4.0

Official publication of the Universidad de Ciencias Aplicadas y Ambientales U.D.C.A, University, Accredited as a High-Quality Institution by the Colombian Ministry of Education.

Received: March 3, 2019 Accepted: May 7, 2021 Edited by: Ingeborg Zenner de Polanía

\begin{abstract}
The milk protein concentrate (MPC) has been extensively studied; however, the MPC partial demineralization through the diafiltration (DF) and its effect on MPC ability to produce milk coagulate products has not been fully explored; therefore, it was considered studying the MPC demineralization process with DF and evaluate the effect of this treatment on the compositional and textural characteristics of enzymatically and acid-coagulated products. The MPC of ultrafiltration was diafiltered by two cycles, later this MPC was used to make a fresh cheese, a set yogurt and stirred yogurt. The application of a single DF cycle removed $22.2 \%$ of the ashes
\end{abstract}

and $8.12 \%$ of the MPC calcium, but no statistically significant differences were present $(\mathrm{P}>0.05)$ between the application of two DF cycles. The cheeses with MPC undergone to one cycle and two cycles of DF were less hard and presented less resistance to chewing, and the set yogurt showed lower springiness values due a total solids and calcium content, that was affected by DF. These phenomena increased the coagulation time and the formation of weaker gels. The DF achieved the maximum milk demineralization in a single cycle.

Keywords: Proteins; Ultrafiltration; Diafiltration; Coagulation; Calcium. 


\section{RESUMEN}

El uso de concentrados de proteína de leche (MPC) ha sido estu-diado ampliamente; sin embargo, su desmineralización parcial por medio de la diafiltración (DF) y el efecto de este tratamiento sobre su aptitud en la elaboración de productos coagulados no está com-pletamente explorada. Se planteó, entonces, estudiar el proceso de desmineralización de un MPC por medio de varios ciclos de DF y evaluar el efecto de este tratamiento sobre las características com-posicionales y texturales de productos coagulados enzimáticamente y por acidez. El MPC, obtenido por ultrafiltración, fue diafiltrado en dos ciclos; luego, el MPC fue usado para elaborar un queso fresco, un yogurt batido y uno cuchareable. La aplicación de un ciclo de DF removió el $22,2 \%$ de las cenizas y $8,12 \%$ del calcio, pero no hubo diferencias significativas $(\mathrm{P}>0,05)$ con respecto a la aplicación de dos ciclos de DF. El queso elaborado con el MPC, con uno y dos ciclos de DF, fue menos duro y presentó menor resistencia a la masticación que el elaborado con MPC sin DF y el yogurt cuchareable presentó menor elasticidad, debido al menor contenido de sólidos totales y calcio, los cuales, fueron afectados por la DF. La desmineralización parcial aumentó el tiempo de coagulación y favoreció la formación de geles más débiles. La DF alcanzó el máximo de desmineralización de la leche en un solo ciclo.

Palabras clave: Proteínas; Ultrafiltración; Diafiltración; Coagulación; Calcio.

\section{INTRODUCTION}

The membrane technology, as a filtration and selective concentration technique applied to the dairy industry, has benefited the develop-ment of technological processes, such as water removal and solid-liquid or liquid-liquid separations (Pouliot, 2008; Lauzin et al. 2020). The ultrafiltration (UF) process is crucial in the dairy industry, in which milk proteins are concentrated by removing lactose, minerals, peptides, water and other solutes with low molecular weight (Ken-neth et al. 2017). As a result of this process, MPC contains both casein and whey proteins in a similar ratio of whole milk (80:20). These products are generally spray-dried, contain protein levels from $42 \%$ to $85 \%$ and are used as protein source in the production of other dairy products such as fermented beverages, cheeses and ice creams (Francolino et al. 2010; Patel \& Patel, 2014; Eshpari et al. 2014; Bruzantin et al. 2016; Lu et al. 2017).

The MPCs in liquid phase can also be applied in the cheese industry since they can improve the nutritional quality of the final product by a greater retention of components, keep a standard composition of the raw material and increase the cheese yield. Furthermore, increasing the total solids in the milk will turn the cheese industry more efficient and a profitable enterprise (Kumar et al. 2013).

The first process developed and patented was the MMV methodology, named after its inventors Maubois, Mocquot \& Vassal, where the industrial production of a cheese based on milk concentrated between 5 to 7 times by UF was obtained, yielding high quality curd (Maubois et al. 1969). In general, the following types of retentate or concentrate can be obtained by concentrating milk through UF: low concentration retentate (VCF: 1.2-2X) (LCR); medium concen-tration retentate (MCR) (VCF: 2-6X) and liquid pre-cheeses (VCF: 6-8X) (Mistry \& Maubois, 2004).

The concentration and buffer capacity of the minerals associated with the caseins ( $\mathrm{Ca}, \mathrm{P}$ and $\mathrm{Mg}$ ) increase in an MPC obtained by UF, generating non-standard textures and flavours in the products with this MPC (Mistry \& Maubois, 2004). The membrane permeable solutes in the DF are diluted in the concentrate by the addition of water and can be re-concentrated in successive stages. Therefore, DF is used to increase the protein content in the UF concentrate, removing lactose, and soluble and insoluble minerals (Brans et al. 2004; Singh, 2007; Gavazzi-April et al. 2018).

The application of DF to milk can lead to the modification of the casein micelles due to the alteration of the minerals associated with their structure and can therefore impact the characteristics of the dairy products (Sandra \& Correding, 2013). DF has also been used to produce whey protein concentrates (WPC) from buttermilk and skimmed milk in order to evaluate their functional properties (Svanborg et al. 2015). These concentrated powder products have been assessed in different processing conditions to improve their functional characteristics (Mao et al. 2012; Banach et al. 2013; Cao et al. 2015; Chenchaiah et al. 2015). Despite the literature in this field, the use of liquid and demineralized MPC in coagulated products has not been fully explored, and the MPC uses are important to dairy industry. Thus, the aim of this work was to study the effect of partial demineralization and protein increase with the application of two DF cycles on a MPC in dairy products like Burgos cheese and set and stirred yogurts by assessing their compositional and textural characteristics.

\section{MATERIALS AND METHODS}

Process of obtaining MPC. The skimmed milk was characterised by Fourier Transform Infrared Spectrometry-FTIR (Milkoscan Foss Instruments, Hillerød, Denmark) for its protein, ash, fat and lactose content. 320L of skimmed milk were used for each experiment. A pilot APV filtration plant (Silkeborg, Denmark) was used for the milk concentration. This plant was equipped with two polyether-sulfone ultrafiltration (UF) membranes (UF-pHt Series GR81PP, Alfa Laval, Lund, Sweden) in parallel with a molecular weight cut-off of $10 \mathrm{kDa}$ and an effective filtration area of $13.6 \mathrm{~m} 2$. The UF process was executed in concentration mode at a transmembrane pressure (TMP) of 4 bar, a temperature of $20^{\circ} \mathrm{C}$ and a volumetric concentration factor (VCF) of 4 , in order to obtain 80L of MPC and 240L of permeate. The ash, calcium and protein contents were determined for the MPC and treatments by the incineration method at $550^{\circ} \mathrm{C}$ (IDF 27, 1964); by inductively coupled plasma mass spectrometry (ICP-MS) (ISO 17294-2, 2003) and by the Kjeldahl method (IDF $320 \mathrm{~B}, 1993)$, respectively. The analyses were performed in triplicate.

The processing conditions, temperature and transmembrane pres-sure for the application of DF to the MPC were determined by previous tests. The MPC was undergone to one 
(M1DF) and two cycles (M2DF) of DF. Osmotized water (240L) with a dilution factor of 4 was added to the MPC for one DF cycle. This mixture was concentrated by UF with an VCF of 4 . For two cycles of DF, the previous process was repeated in a successive way. 80L of each diafiltered product were recovered and the membrane was chemi-cally cleaned at the end of each experiment.

Burgos cheese preparation. The cheese was prepared using the MMV methodology (Maubois et al. 1969). The protein content in each MPC was standardized to $12 \%(\mathrm{w} / \mathrm{v})$. The MPC was pasteur-ized at $75^{\circ} \mathrm{C}$ for $5 \mathrm{~min}$ and cooled to $35^{\circ} \mathrm{C}$. Then, $0.02 \%$ of $\mathrm{CaCl} 2$ was added and the coagulant enzyme was applied (Chy-Max, Chr. Hansen, Denmark). After $30 \mathrm{~min}$, the product was stored at $5^{\circ} \mathrm{C}$ by $24 \mathrm{~h}$ until the analyses were performed.

Set and stirred yogurt preparation. The protein content in each MPC was standardized to $4 \%(\mathrm{w} / \mathrm{v})$. The MPC samples were heated to $75^{\circ} \mathrm{C}$, homogenized at 200 bar and pasteurized at $95^{\circ} \mathrm{C}$ for $5 \mathrm{~min}$. They were then cooled to $43^{\circ} \mathrm{C}$, inoculated with Lactobacillus delbrueckii subsp. bulgaricus and Streptococcus thermophilus and incubated at $42.5^{\circ} \mathrm{C}$ until they reached a $\mathrm{pH}$ of 4.6. Subsequently, some yogurt was remained without any further stirring (set yogurt), whereas some others were stored at $5^{\circ} \mathrm{C}$ for $12 \mathrm{~h}$ and their curd was broken manually to transform the stirred yogurt. Both set and stirred yogurts were stored at $5^{\circ} \mathrm{C}$ by $24 \mathrm{~h}$ until their analysis.

Textural properties of the yogurts and cheese. The firmness $(\mathrm{N})$, springiness $(\mathrm{mm})$ and cohesiveness of the set yogurt were assessed using a texture analyzer (TA-XTplus, Stable Micro Systems, Godalm-ing, UK) with a $0.5 \mathrm{~mm}$ probe (SMSP/0.5) and equipped with a $25 \mathrm{~kg}$ load cell. The samples were introduced into a container where their fermentation took place. The parameters for the test were: $1 \mathrm{~mm} / \mathrm{s}$ pre-test speed, $0,5 \mathrm{~mm} / \mathrm{s}$ test speed, $0,5 \mathrm{~mm} / \mathrm{s}$ post-test speed, a compression distance of $15 \mathrm{~mm}$ and a test time of 5s (Ferragut et al. 2009; Serra et al. 2009).

Regarding the stirred yogurt, a back-extrusion test was performed using the same texture analyzer and the same load cell to determine its firmness $(\mathrm{N})$, consistency (N.s), cohesiveness and viscosity index (N.s). The probe was the back-extrusion ring with a $35 \mathrm{~mm}$ disc and calibrated at a height of $80 \mathrm{~mm}$. For this test, the cylinder was filled with the sample and refrigerated for $1 \mathrm{~h}$. The test conditions were: $1 \mathrm{~mm} / \mathrm{s}$ pre-test speed, $1 \mathrm{~mm} / \mathrm{s}$ test speed, $10 \mathrm{~mm} / \mathrm{s}$ post-test speed and a compression distance of $30 \mathrm{~mm}$ (Serra et al. 2009; Najgebauer-Lejko et al. 2014). For the yogurts, six samples were used for each textural test.

The maximum deformation supported by the cheese samples before fracture was evaluated in previous tests. The cheese was portioned into $2 \mathrm{~cm}^{3}$ cubes to perform the texture profile analysis (TPA) using the texture analyzer previously described, equipped with the $100 \mathrm{~mm}$ probe (SMSP/100) and the same load cell. The parameters for the test were: $1 \mathrm{~mm} / \mathrm{s}$ pre-test speed, $1 \mathrm{~mm} / \mathrm{s}$ test speed, $1 \mathrm{~mm} / \mathrm{s}$ post-test speed, and $35 \%$ strain with a $5 \mathrm{~s}$ waiting time between the two cycles (Gutiérrez et al. 2013). The TPA characteristics were firmness $(\mathrm{N})$, springiness, cohesiveness and and chewiness $(\mathrm{N})$. Six replicates of each textural test were performed on the cheese samples.

Composition analysis of products. The ash content was calculated by the method of incineration at $550^{\circ} \mathrm{C}$ (IDF 27, 1964), the calcium content by ICP-MS (ISO 17294-2, 2003), the protein content by the Kjeldahl method (IDF 20B, 1993) and the total solids by gravimetric method at $100^{\circ} \mathrm{C}$ (IDF 4A, 1982). The fat content for the cheese was measured by the Soxhlet method (IDF 5B, 1986) and for the yogurt by the Rose-Gottlieb method (IDF 1D, 1996).

Statistical analysis. The results were presented as means + SD. For the response variables (physical, chemical and compositional charac-teristics) of each product, a one-way analysis of variance (ANOVA) was used at a 5\% significance level, considering the factor as the number of diafiltrations: without DF (MPC) (control), one cycle (M1DF) and two cycles (M2DF). The least significant difference (LSD) was used to compare the treatments, when significant dif-ferences were found. All analyses were performed using Statgraphic Centurion 16.1. (Statpoint Technologies, INC).

\section{RESULTS AND DISCUSSION}

Process for obtaining MPC, M1DF and M2DF. The skimmed milk used in the study was composed of $33,3 \mathrm{~g} / \mathrm{L}$ of protein, $6,6 \mathrm{~g} / \mathrm{L}$ of ash, $0,7 \mathrm{~g} / \mathrm{L}$ of fat, $49,3 \mathrm{~g} / \mathrm{L}$ of lactose, $92,9 \mathrm{~g} / \mathrm{L}$ of total solids and $125,83 \mathrm{mg} / 100 \mathrm{~mL}$ of calcium, the milk used for the concentration process is within the parameters required by Colombian legislation and by other authors, to categorize it as skimmed milk (Ministerio de la Protección Social, 2006; Fox et al. 2015). The composition of MPC, M1DF and M2DF is presented in the table 1 . The ash contents were $9,8 \%$ and $9,6 \%$ and the calcium contents were $369,2 \mathrm{mg} / 100 \mathrm{~g}$ and $357,5 \mathrm{mg} / 100 \mathrm{~g}$ for M1DF and M2DF, respec-tively, and were significantly lower $(\mathrm{P}<0.05)$ than those presented by the MPC which were $12,6 \%$ and 401,8 $\mathrm{mg} / 100 \mathrm{~g}$, respectively. Banach et al. (2013) obtained similar results when applying DF to an MPC, removing part of the ash content, mainly from the soluble fraction of minerals.

Likewise, a removal of soluble minerals with DF has been reported, mainly $\mathrm{K}, \mathrm{Na}$ and $\mathrm{Cl}$ (Chenchaiah et al. 2015; Kenneth et al. 2018). Based on this, it could be indicated that a large part of the soluble fraction of minerals was removed in the first DF cycle and, for the second cycle, the colloidal minerals (Ca, $\mathrm{Mg}$ and $\mathrm{P}$ ) remained, which are associated with the structure of the milk and solubilized slowly (Mistry \& Mauboius, 2004; Gaucheron, 2005). Such behavior was observed in this investigation because ashes were reduced in $\mathrm{M} 1 \mathrm{DF}$ and $\mathrm{M} 2 \mathrm{DF}$ with respect to $\mathrm{MPC}$, going from $12.6 \%$ to $9.8 \%$ and $9.6 \%$ in $\mathrm{MPC}, \mathrm{M} 1 \mathrm{DF}$ and $\mathrm{M} 2 \mathrm{DF}$, respectively. Thus, a second DF cycle is not necessary because the removal of minerals from the samples was not significant between M1DF and M2DF (Table 1).

Composition of processed products. No significant differences $(\mathrm{P}>0.05)$ in protein content were found between the cheeses and yogurts made with MPC, M1DF and M2DF, with $122.5 \mathrm{~g} / \mathrm{kg}, \quad 121.2 \mathrm{~g} / \mathrm{kg}$ and $122.9 \mathrm{~g} / \mathrm{kg}$, respectively, confirming the correct milk 
standardization. On the other hand, significant differences $(\mathrm{P}<0.05)$ were found in the total solids, ash and calcium contents among the products made with MPC compared to those prepared with M1DF and M2DF. These results indicated that the DF process was effec-tive in UF-permeable solutes removal, such as lactose and ash, in which calcium was the most representative. However, it is important to note that these components are soluble fractions removed with the water used in the DF. Gaucheron (2011) showed that the milk calcium had a soluble and micellar fraction that represents the $30 \%$ and $70 \%$ of the total calcium, respectively. These data agree with the calcium fraction removed between MPC and M1DF (Table 2).

The DF using the UF membrane is a technology aimed at obtaining MPC and WPC with high protein content, since the amount of protein within the total solids of the product increases by decreasing lactose and soluble ions in the concentrate (Ferrer et al. 2014). The calcium content was reduced from $401.8 \mathrm{mg} / 100 \mathrm{~g}$ to 369. $\mathrm{mg} / 100 \mathrm{~g}$ in a M1DF and $357.5 \mathrm{mg} / 100 \mathrm{~g}$ in M2DF, and the total solids from $179.3 \mathrm{~g} / \mathrm{kg}$ on MPC to $127.0 \mathrm{~g} / \mathrm{kg}$ on M2DF. These results agree with Eshpari et al. (2014) who found significant differences in the lactose content between an MPC (UF) and an MPC (UF) with a DF cycle and Ferrer et al. (2014) found a significant reduction in the soluble and insoluble calcium content in an MPC when different volumes of DF were applied. In contrast with these reductions, on the concentrate samples used for Burgos cheese, the protein accounted for $69 \%$ of total solids on MPC and on M1DF and M2DF the $87.1 \%$ and and $95.9 \%$ of total solids, respectively, these data indicate that de DF by UF is effective in milk proteins concentration. On the concentrate samples used to make yogurt the trend of protein concentration was similar because on the MPC the protein represented a $38.3 \%$ of the total solids and on the M1DF and M2DF the $75.3 \%$ and $61.9 \%$, respectively.

Textural properties of processed products. The cheeses made with MPC showed more firmness and resistance to chewing than those made with M1DF and M2DF, which can be explained by the lower calcium content in diafiltered milk that went from $389.6 \mathrm{mg} / 100 \mathrm{~g}$ of MPC to 356.2 and $358,6 \mathrm{mg} / 100 \mathrm{~g}$ of M1DF and M2DF, respectively (Tables 2 and 3).

This mineral is important for the enzymatic coagulation of milk, especially for its soluble fraction, which is involved in the secondary phase of the coagulation process when the casein micelles interact with the rennet (Ferrer et al. 2014; Eshpari et al. 2015), then the milk with lower soluble calcium resulted in weaker enzymatic curds.

The firmness of dairy gels obtained enzymatically from MPC56 and MPC85 standardized to equivalent levels of protein was compared, and the gel made with MPC56 was harder due to the higher content of soluble calcium (Sandra \& Corredig, 2013). The soluble calcium in milk decreases with DF; therefore, gels with lower firmness are obtained when this milk is enzymatically

Table 1. Characterisation of the MPC*.

\begin{tabular}{|c|c|c|c|}
\hline & \multicolumn{3}{|c|}{ Treatments } \\
\hline Compounds & MPC & M1DF & M2DF \\
\hline Protein $(\mathrm{g} / \mathrm{kg})$ & $122.5 \pm 0.9 \mathrm{a}$ & $121.2 \pm 1.0 \mathrm{a}$ & $122.9 \pm 1.2 \mathrm{a}$ \\
\hline Ash $(\%)$ & $12.6 \pm 1.1 \mathrm{a}$ & $9.8 \pm 0.9 \mathrm{~b}$ & $9.6 \pm 1.0 \mathrm{~b}$ \\
\hline Calcium $(\mathrm{mg} / 100 \mathrm{~g})$ & $401.8 \pm 13.3 \mathrm{a}$ & $369.2 \pm 7.6 \mathrm{~b}$ & $357.5 \pm 12.7 \mathrm{~b}$ \\
\hline
\end{tabular}

* The results are the mean \pm standard deviation. Values of the same row with different letters present a statistically significant difference $(\mathrm{P}<0.05)$.

Table 2. Composition of Burgos type cheese and set or stirred yoghurts*.

\begin{tabular}{|c|c|c|c|c|c|c|}
\hline \multirow{2}{*}{ Characteristicas } & \multicolumn{4}{|c|}{ Treatments } \\
\cline { 2 - 7 } & \multicolumn{3}{|c|}{ Burgos type cheese } & Moghurt* \\
\cline { 2 - 7 } & MPC & M1DF & M2DF & MPC & M1DF & M2DF \\
\hline Total solids $(\mathrm{g} / \mathrm{kg})$ & $17.3 \pm 5.7 \mathrm{a}$ & $138.9 \pm 2,3 \mathrm{~b}$ & $127.0 \pm 7.9 \mathrm{c}$ & $108.8 \pm 10.8 \mathrm{a}$ & $58.3 \pm 5.1 \mathrm{~b}$ & $66.9 \pm 0.9 \mathrm{~b}$ \\
\hline Protein $(\mathrm{g} / \mathrm{kg})$ & $119.4 \pm 5.9 \mathrm{a}$ & $121.1 \pm 2.4 \mathrm{a}$ & $121.9 \pm 2.2 \mathrm{a}$ & $41.7 \pm 2.2 \mathrm{a}$ & $43.9 \pm 1.4 \mathrm{a}$ & $41.2 \pm 0.6 \mathrm{a}$ \\
\hline Ash $(\mathrm{g} / \mathrm{kg})$ & $14.2 \pm 0.9 \mathrm{a}$ & $10.8 \pm 0.5 \mathrm{~b}$ & $11.5 \pm 0.3 \mathrm{~b}$ & $7.9 \pm 0.8 \mathrm{a}$ & $4.3 \pm 0.4 \mathrm{~b}$ & $3.5 \pm 0.2 \mathrm{~b}$ \\
\hline Calcium $(\mathrm{mg} / 100 \mathrm{~g})$ & $389.6 \pm 7.6 \mathrm{a}$ & $356.2 \pm 7.0 \mathrm{~b}$ & $358.6 \pm 3.0 \mathrm{~b}$ & $158.8 \pm 2.4 \mathrm{a}$ & $116.8 \pm 9.4 \mathrm{~b}$ & $109.1 \pm 3.5 \mathrm{~b}$ \\
\hline
\end{tabular}

*The results are the mean \pm standard deviation. Values on the same row with different letters present a statistically significant difference for each product $(\mathrm{P}<0.05)$. 
coagulated (Ferrer et al. 2014; Liu et al. 2017). This behavior was similar to that observed in this investigation where the firmness was lower in the Burgos cheese made from M1DF and M2DF with respect to the firmness of the cheese obtained from the MPC (Table 3) with values of $349.7 \mathrm{~N}, 290 \mathrm{~N}$ and $261.5 \mathrm{~N}$ for the cheese made from MPC, M1DF and M2DF, respectively. This is attributed to the fact that the calcium was not significantly reduced between M1DF and M2DF but there were differences with respect to MPC. The lesser firmness in the cheeses with M1DF and M2DF can also be generated because the DF increases the presence of the $K, \alpha$-s and $\beta$ caseins in the soluble phase, which increases the rennet coagulation time and reduces the clots firmness (Sandra \& Corredig, 2013; Ferrer et al. 2014).

The yogurt is a coagulated product obtained through the fermentation of milk by lactic acid bacteria, the yogurt coagulation is caused by the hydrophobic and electrostatic interactions between proteins when the milk reaches the isoelectric point of the caseins $(\mathrm{pH}=4.6)$ (Lourens-Hattingh \& Vijoen, 2001; Sandoval-Castilla et al. 2004). Even at this point, the calcium phosphate is partially separated from the casein micelles (Fox, 2001; Chandan et al. 2006; Ferrer et al. 2014; Lauzin et al. 2020).

Schulz-Collins \& Senge (2004) did not find significant differences in the yogurt firmness made from demineralized milk and explained that adding calcium to milk has no significant effect on the acid coagulation of dairy products. In this investigation, no significant differences were found in the firmness with $22.4 \mathrm{~g}, 26.4 \mathrm{~g}$, and $24.4 \mathrm{~g}$ to the stirred yogurt made from MPC, M1DF and M2DF, respectively and $27.3 \mathrm{~g}, 32.1 \mathrm{~g}$ and $30.3 \mathrm{~g}$ to the set yogurt made from MPC, M1DF and M2DF, respectively. Sandoval-Castilla et al. 2004, Supavititpatana et al. 2008 and Hashim et al. 2009 reported set yogurts with higher firmness, adhesiveness and springiness values because the raw material was skimmed milk standardized to $4 \%$ protein and supplemented with starch, gelatin or fiber that helped improve the general characteristics of the product's texture.

When diafiltered milk is used in the set yogurt preparation a less elastic product is obtained. This effect is attributed to the lower content of total solids in the M1DF and M2DF products (Table 2) since DF in UF membranes removes lactose and milk minerals. When milk solids like minerals, specifically the calcium is removed from the casein micelles, acid gels with higher loss tangents (tan $\delta$ ) are generated, which explains their lower springiness (Haque \& Sharma, 2002; Ozcan et al. 2011).

The firmness, consistency, cohesiveness and viscosity index of stirred yogurt showed no significant differences $(P>0.05)$ among the samples (Table 4). Najgebauer-Lejko et al. (2014) prepared a similar product with semi-skimmed milk supplemented with green tea, and found the values of firmness, consistency, cohesiveness and viscosity index lower than those reported in this study for all treatments. The calcium content reduction in the milk did not affect the textural properties of the stirred yogurt, which can be considered as a concentrated dispersion of gel particles in serum (Marle et al. 1999).

From the results obtained it can be concluded that the UF application combined with DF is an effective way to achieve a partial MPC demineralization. However, no significant difference in the mineral content was found when more than one DF cycle was ap-plied. The textural differences of the fresh cheese were attributed to the mineral imbalance generated by the DF of the MPC, mainly in the calcium content. When acid coagulation happened in the yogurts, no significant effects of partial MPC demineralization were observed. The filtration effect was significant on protein structures and milk mineral content, this change affects the composition and texture of dairy products. Further studies are needed on the sensory differences and other physicochemical characteristics of the dairy products made from these treated milks in order to establish more accurate effects on their quality.

Acknowledgements. COLCIENCIAS, Productos Lácteos Aura and the Universidad Nacional de Colombia are acknowledged for the financial support to E. Bejarano-Toro provided through contract 575 of 2013. Conflict of interests: The paper was prepared and revised by all authors, who declare that there is no conflict of interest that jeopardizes the validity of the results.

Table 3. Texture profile analysis for cheeses made with MPC, M1DF and M2DF.

\begin{tabular}{|c|c|c|c|}
\hline \multirow{2}{*}{ Characteristics } & \multicolumn{3}{|c|}{ Treatments } \\
\cline { 2 - 4 } & MPC & M1DF & M2DF \\
\hline Firmness $(\mathrm{N})$ & $349.7 \pm 13.4 \mathrm{a}$ & $290.0 \pm 10.5 \mathrm{~b}$ & $261.5 \pm 21.0 \mathrm{~b}$ \\
\hline Cohesiveness & $0.87 \pm 0.0 \mathrm{a}$ & $0.87 \pm 0.0 \mathrm{a}$ & $0.86 \pm 0.0 \mathrm{a}$ \\
\hline Springiness $(\mathrm{mm})$ & $0.97 \pm 0.0 \mathrm{a}$ & $0.97 \pm 0.0 \mathrm{a}$ & $0.97 \pm 0.0 \mathrm{a}$ \\
\hline Chewiness $(\mathrm{N})$ & $295.1 \pm 21.4 \mathrm{a}$ & $234.7 \pm 19.4 \mathrm{~b}$ & $209.9 \pm 16.8 \mathrm{~b}$ \\
\hline
\end{tabular}

The results are the mean \pm standard deviation. Values on the same row with different letters present a statistically significant difference $(\mathrm{P}<0.05)$. 
Table 4. Textural characteristics of yoghurts made with MPC, M1DF and M2DF.

\begin{tabular}{|c|c|c|c|c|}
\hline \multirow{3}{*}{ Product } & \multirow{3}{*}{ Characteristic } & \multicolumn{3}{|c|}{ Treatments } \\
\cline { 2 - 5 } & & MPC & M1DF & M2DF \\
\hline \multirow{3}{*}{ Stirred yogurt } & Firmness (N) & $0.219 \pm 0.013 \mathrm{a}$ & $0.259 \pm 0.025 \mathrm{a}$ & $0.239 \pm 0.018 \mathrm{a}$ \\
\cline { 2 - 5 } & Consistency (N.s) & $5.78 \pm 0.504 \mathrm{a}$ & $6.87 \pm 0.62 \mathrm{a}$ & $6.25 \pm 0.56 \mathrm{a}$ \\
\cline { 2 - 5 } & Cohesiveness * & $17.5 \pm 1.0 \mathrm{a}$ & $19.1 \pm 1.9 \mathrm{a}$ & $17.8 \pm 1.5 \mathrm{a}$ \\
\cline { 2 - 5 } & Viscosity index (N.s) & $0.29 \pm 0.021 \mathrm{a}$ & $0.356 \pm 0.037 \mathrm{a}$ & $0.265 \pm 0.058 \mathrm{a}$ \\
\hline \multirow{3}{*}{ Set yogurt } & Firmness (N) & $0.267 \pm 0.025 \mathrm{a}$ & $0.314 \pm 0.031 \mathrm{a}$ & $0.297 \pm 0.029 \mathrm{a}$ \\
\cline { 2 - 5 } & Cohesiveness & $0.4 \pm 0.0 \mathrm{a}$ & $0.36 \pm 0.0 \mathrm{a}$ & $0,36 \pm 0.0 \mathrm{a}$ \\
\cline { 2 - 5 } & Springiness (mm) & $0.97 \pm 0.0 \mathrm{a}$ & $0.93 \pm 0.0 \mathrm{~b}$ & $0.94 \pm 0.0 \mathrm{~b}$ \\
\hline
\end{tabular}

The results are the mean \pm standard deviation. Values of the same row with different letters present a statistically significant difference $(\mathrm{P}<0.05)$.

*Absolute value

0.2670 .3140 .297

\section{REFERENCES}

1. BANACH, J.; LIN, Z.; LAMSAL, B.P. 2013. Enzymatic modification of milk protein concentrate and characterization of resulting functional properties. LWT'Journal. 54(2):397403.

https://doi.org/10.1016/j.lwt.2013.06.023

2. BRANS, G.; SCHROËN, C.; VAN DER SMAN, R.; BOOM, R. 2004. Membrane fractionation of milk: state of the art and challenges. J. Membrane Science. 243(1-2):263-272. https://doi.org/10.1016/j.memsci.2004.06.029

3. BRUZANTIN, F.; DANIEL, J.; DA SILVA, P.; SPOTO, M. 2016. Physicochemical and sensory characteristics of fatfree goat milk yogurt with added stabilizers and skim milk powder fortification. J. Dairy Science. 99(5):3316-3324. https://doi.org/10.3168/jds.2015-10327

4. CAO, J.; ZHANG, W.; WU, S.; LIU, C.; LI, Y.; LI, H.; ZHANG, L. 2015. Short communication: Effects of nanofiltration and evaporation on the physiochemical properties of milk protein during processing of milk protein concentrate. J. Dairy Science. 98(1):100-105. https://doi.org/10.3168/jds.2014-8619

5. CHANDAN, R.C.; O'RELL, K.R. 2006. Manufacture of Various Types of Yogurt. En: Chandan, R.; White, C.; Kilara, A.; Hui, Y. (eds). Manufacturing Yogurt and Fermented Milks. Blackwell Publishing, Ames, Iowa, USA, p.211-213. https://doi.org/10.1002/9780470277812.ch13

6. CHENCHAIAH, M.; SALUNKE, P.; BISWAS, A.; KOMMINENI, A.; METZGER, L. 2015. Manufacture of modi- fied milk protein concentrate utilizing injection of carbon dioxide. J. Dairy Science. 98(6):3577-3589.

https://doi.org/10.3168/jds.2014-8946

7. ESHPARI, H.; JIMENEZ-FLORES, R.; TONG, P.; CORREDING, M. 2015. Partial calcium depletion during membrane filtration affects gelation of reconstituted milk protein concentrates. J. Dairy Science. 98(12):8454-8463. https://doi.org/10.3168/jds.2015-9856

8. ESHPARI, H.; TONG, P.; CORREDIG, M. 2014. Changes in the physical properties, solubility, and heat stability of milk protein concentrates prepared from partially acidified milk. J. Dairy Science. 97(12):7394-7401. https://doi.org/10.3168/jds.2014-8609

9. FERRAGUT, V.; CRUZ, N.; TRUJILLO, A.; GUAMIS, B.; CAPELLAS, M. 2009. Physical characteristics during storage of soy yogurt made from ultra-high pressure homogenized soymilk. J. Food Engineering. 92(1):63-69. https://doi.org/10.1016/j.jfoodeng.2008.10.026

10. FERRER, M.; ALEXANDER, M.; CORREDING, M. 2014. Changes in the physico-chemical properties of casein micelles during ultrafiltration combined with diafiltration. LWT-Food Science and Technology. 59(1):173-180. https://doi.org/10.1016/j.lwt.2014.04.037

11. FOX, P. 2001. Milk proteins as food Ingredients. Int. J. Dairy Technology. 54(2):41-55. https://doi.org/10.1046/j.1471-0307.2001.00014.x

12. FOX, P.; UNIACKE-LOWE, T.; MCSWEENEY, P.; O’MAHONY, J. 2015. Production and Utilization of Milk. 
En: Fox, P.; Uniacke-Lowe, T.; McSweeney, P.; O’Mahony, J. (eds). Dairy Chemistry and Biochemistry. Ed. Springer International Publishing, Suiza. p.1-3.

13. FRANCOLINO, S.; LOCCI, F.; GHIGLIETTI, R.; LEZZI, R.; MUCCHETTI, G. 2010. Use of milk protein concentrate to standardize milk composition in Italian citric Mozzarella cheese making. LWT-Journal. 43(2):310-314. https://doi.org/10.1016/j.lwt.2009.08.007

14. GAUCHERON, F. 2005. The minerals of milk. Reproduction Nutrition Development. 45(4):473-483. https://doi.org/10.1051/rnd:2005030

15. GAUCHERON, F. 2011. Milk and Dairy Products: A Unique Micronutrient Combination. J. American College of Nutrition. 30:400S-409S. http://dx.doi.org/10.1080/07315724.2011.10719983

16. GAVAZZI-APRIL, C.; BENOIT, S.; DOYEN, A.; BRITTEN, M.; POULIOT, Y. 2018. Preparation of milk protein concentrates by ultrafiltration and continuous diafiltration: effect of process design on overall efficiency. J. Dairy Science. 101:9670-9679. https://doi.org/10.3168/jds.2018-14430

17. GUTIÉRREZ, N.; TRANCOSO, N.; LEAL, M. 2013. Texture profile analysis of Fresh cheese and Chihuahua cheese using miniature cheese models. Tecnociencia Chihuahua. 7(2):65-74.

18. HAQUE, Z.; SHARMA, M. 2002. Influence of cation sequestering and $\mathrm{pH}$ on quiescent thermal association of lactoglobulin NB from fresh Cheddar whey: an insight into gelation mechanism. Food Science and Technology Research. 8(4):311-316. https://doi.org/10.3136/fstr.8.311

19. HASHIM, I.; KGALIL, A.; AFIFI, H. 2009. Quality characteristics and consumer acceptance of yogurt fortified with date fiber. J. Dairy Science. 92(11):5403-5407. https://doi.org/10.3168/jds.2009-2234

20. INTERNATIONAL DAIRY FEDERATION, IDF. 1964. Determination of the ash content of processed cheese products. Standard FIL-IDF 27:1964. International Dairy Federation, Brussels, Belgium.

21. INTERNATIONAL DAIRY FEDERATION, IDF. 1986. Cheese and processed cheese product: determination of fat content- gravimetric method (Reference Method). Standard FIL-IDF 5B:1986. International Dairy Federation, Brussels Belgium.

22. INTERNATIONAL DAIRY FEDERATION, IDF. 1993. Milk: determination of nitrogen content. Standard FIL-
IDF 20B:1993. International Dairy Federation, Brussels Belgium.

23. INTERNATIONAL DAIRY FEDERATION, IDF. 1996. Milk: Determination of fat content (Röse-Gottlieb gravimetric method). IDF Standard 1D. Standard FIL-IDF 1D: 1996. International Dairy Federation, Brussels Belgium.

24. INTERNATIONAL STANDARD ISO. 2003. ISO: 17294-2: Water quality: Application of inductively coupled plasma mass spectrometry (ICP-MS), Parte 2: Determination of 62 elements. Ginebra, Suiza.

25. KENNETH, S.; DUSTAN, D.; MARTIN, G. 2018. Influence of diafiltration on flux decline during skim milk ultrafiltration. International Dairy Journal. 87:67-74. https://doi.org/10.1016/j.idairyj.2018.07.021

26. KENNETH, S.; MALAVIKA, H.; DALTON, J.; DAVE, E.; GREGORY, J. 2017. Mechanisms of flux decline in skim milk ultrafiltration: A review. J. Membrane Science. 523:144162.

https://doi.org/10.1016/j.memsci.2016.09.036

27. KUMAR, P.; SHARMA, N.; RANJAN, R.; KUMARM, S.; BHAT, Z.; JEONG, D. 2013. Perspective of membrane technology in dairy industry: a review. Asian-Australasian J. Animal Science. 26(9):1347-1358. http://dx.doi.org/10.5713/ajas.2013.13082

28. LAUZIN, A.; POULIOT, Y.; BRIT'TEN, M. 2020. Understanding the differences in cheese-making properties between reverse osmosis and ultrafiltration concentrates. J. Dairy Science. 103:201-209. https://doi.org/10.3168/jds.2019-16542

29. LIU, D.; LI, J.; JIE, Z.; LIU, X.; WANG, M.; YACINE, H.; REGENSTEIN, J.; ZHOU, P. 2017. Effect of partial acidification on the ultrafiltration and diafiltration of skim milk: Physico-chemical properties of the resulting milk protein concentrates. J. Food Engineering. 212:55-64. https://doi.org/10.1016/j.jfoodeng.2017.05.019

30. LOURENS-HATTINGH, A.; VILJOEN, B. 2001. Yogurt as probiotic carrier food. Internal Dairy J. 11(1-2):1-17. https://doi.org/10.1016/S0958-6946(01)00036-X

31. LU, Y.; MCMAHON, D.; VOLLMER, A. 2017. Investigating rennet coagulation properties of recombined highly concentrated micellar casein concentrate and cream for use in cheese making. J. Dairy Science. 100(2):892-900. https://doi.org/10.3168/jds.2016-11648

32. MAO, X.; TONG, P.; GUALCO, S.; VINK, S. 2012. Effect of $\mathrm{NaCl}$ addition during diafiltration on the solubility, hydrophobicity, and disulfide bonds of $80 \%$ milk protein 
concentrate powder. J. Dairy Science. 95(7):3481-3488. https://doi.org/10.3168/jds.2011-4691

33. MARLE, M.; VAN DEN ENDE, D.; DE KRIUF, C.; MELLEMA, J. 1999. Steady-shear viscosity of stirred yogurts with varying ropiness. J. Rheology. 43:1643-1662. https://doi.org/10.1122/1.551065

34. MAUBOIS, J.; MOCQUOT, G.; VASSAL, L. 1969. Procédé de traitement du lait et de sous produits laitiers. Paris, France. Patent 2052121.

35. MINISTERIO DE LA PROTECCIÓN SOCIAL. 2006. Ordinance 616. Bogotá, Colombia.

36. MISTRY, V.; MAUBOIS, J. 2004. Application of Membrane Separation Technology to Cheese Production. In: Cheese: Chemistry, Physics and Microbiology. El Sevier, Wisconsin, USA. p.261-262.

37. NAJGEBAUER-LEJKO, D.; ŻMUDZIŃSKI, D.; PTASZEK, A.; SOCHA, R. 2014. Textural properties of yogurts with green tea and Puerh tea additive. Internal J. Food Science and Technology. 49(4):1149-1158.

https://doi.org/10.1111/ijfs.12411

38. OZCAN, T.; HORNE, D.; LUCEY, J. 2011. Effect of increasing the colloidal calcium phosphate of milk on the texture and microstructure of yogurt. J. Dairy Science. 94(11):52785288.

https://doi.org/10.3168/jds.2010-3932

39. PATEL, H.; PATEL, S. 2014. Milk protein concentrates: manufacturing and applications. Dairy Research Institute: Technical Report. p.2-3.

40. POULIOT, Y. 2008. Membrane processes in dairy technology-From a simple idea to worldwide panacea. Internal Dairy J. 18(7):735-740. https://doi.org/10.1016/j.idairyj.2008.03.005
41. SANDOVAL-CASTILLA, O.; LOBATO-CALLEROS, C.; AGUIRRE-MANDUJANO, E.; VERNON-CARTER, E. 2004. Microstructure and texture of yogurt as influenced by fat replacers. Internal Dairy J. 14(2):151-159. https://doi.org/10.1016/S0958-6946(03)00166-3

42. SANDRA, S.; CORREDING, M. 2013. Rennet induced gelation of reconstituted milk protein concentrates: The role of calcium and soluble proteins during reconstitution. Internal Dairy J. 29(2):68-74. https://doi.org/10.1016/j.idairyj.2012.10.011

43. SCHULZ-COLLINS, D.; SENGE, B. 2004. Acid and Acid/ Rennet-curd Cheeses Part A: Quark, Cream Cheese and Related Varieties. In: Fox, P.; McSweeney, P.; Cogan, T.; Guinee, T. Cheese: Chemistry, Physics and Microbiology. Elservier (Wisconsin, USA). p.303-304.

44. SERRA, M.; TRUJILLO, B.; GUAMIS, B.; FERRAGUT, V. 2009. Evaluation of physical properties during storage of set and stirred yogurts made from ultra-high-pressure homogenization-treated milk. Food Hydrocolloids. 23(1):8291.

https://doi.org/10.1016/j.foodhyd.2007.11.015

45. SINGH, H. 2007. Interactions of milk proteins during the manufacture of milk powders. Le Lait. 87(4-5):413-423.

46. SUPAVITITPATANA, P.; WIRJANTORO, T.; APICHARTSRANGKOON, A.; RAVIYAN, P. 2008. Addition of gelatin enhanced gelation of corn-milk yogurt. Food Chemistry. 106(1):211-216 https://doi.org/10.1016/j.foodchem.2007.05.058

47. SVANBORG, S.; JOHANSEN, A.; ABRAHAMSEN, R.; SKEIE, S. 2015. The composition and functional properties of whey protein concentrates produced from buttermilk are comparable with those of whey protein concentrates produced from skimmed milk. J. Dairy Science. 98(9):5829-5840.

https://doi.org/10.3168/jds.2014-9039 